\title{
PENGARUH PENGGUNAAN PS BALL TERHADAP BALOK BETON BERTULANG DENGAN PEMBEBANAN MONOTONIK DAN PEMBEBANAN SIKLIK
}

\author{
Tan Lie Ing ${ }^{(1)}$, Ronald Simatupang ${ }^{(2)}$, Deni Setiawan ${ }^{(3)}$ \\ ${ }^{(1)}$ DosenProgram Studi S-1 Teknik Sipil, Fakultas Teknik, Universitas Kristen Maranatha \\ ${ }^{(2)}$ Dosen Program Studi S-1 Teknik Sipil, Fakultas Teknik, Universitas Kristen Maranatha \\ ${ }^{(3)}$ Dosen Program Studi S-1 Teknik Sipil, Fakultas Teknik, Universitas Kristen Maranatha \\ Jalan Prof. Drg. Suria Sumantri No. 65, Bandung 40164 \\ e-mail: lieing.tan@yahoo.com
}

\begin{abstract}
ABSTRAK
PS Ball sebagai bahan pengganti pasir dan bahan pengisi telah dilakukan dan disimpulkan dapat digunakan sebagai bahan konstruksi bangunan. PS Ball sebagai bahan konstruksi bangunan lebih unggul dibanding pasir dalam hal kuat tekan, kekerasan, dan anti-weathering. Saat ini, bahan konstruksi bangunan yang sering digunakan adalah beton. Inovasi untuk menciptakan bahan penyusun beton yang ramah lingkungan sangat diperlukan sehingga dilakukan penelitian pengaruh penggunaan $P S$ Ball pada balok beton bertulang dengan pembebanan monotonik dan pembebanan siklik.

Tujuan penelitian adalah mengevaluasi pengaruh penggunaan PS Ball terhadap elemen struktur beton bertulang dengan pembebanan monotonik dan pembebanan siklik serta menganalisis perilaku elemen struktur setelah dibebani beban monotonik dan beban siklik. Pengujian dilakukan dengan metode eksperimental.

Berdasarkan hasil analisis diperoleh beton bertulang menggunakan PS Ball dapat menahan beban sebesar $90 \mathrm{kN}$ sedangkan beton bertulang tanpa PS Ball sebesar $79 \mathrm{kN}$ pada saat pembebanan monotonik. Pada pembebanan siklik, disipasi energi kumulatif beton bertulang menggunakan PS Ball kinerjanya lebih baik daripada beton bertulang tanpa PS Ball dan kurva histerisis beton bertulang menggunakan PS Ball lebih stabil dan tidak terjadi pinching.
\end{abstract}

Kata kunci: PS Ball, Balok Beton Bertulang, Beban Monotonik, Beban Siklik, Kinerja

\begin{abstract}
PS Ball as a substitute of sand and filler has been conducted and concluded that PS Ball can be used as construction materials. PS Ball as building material is better than sand in terms of compressive strength, hardness, and anti-weathering. Nowadays, construction material frequently used is concrete. Innovation to create environmentally friendly building concrete blocks is needed so it is necessary to do research on the impact of PS Ball on the use of reinforced concrete beams with monotonic and cyclic loading.

The purpose of this research is to evaluate the effect of the use of PS Ball against the reinforced concrete structural elements of the monotonic and cyclic loading and to analyze the behavior of structural elements after being loaded by monotonic and cyclic loading. Testing is conducted with experimental methods.

Based on the analysis results of reinforced concrete using PS Ball, it can withstand a load of 90 $k N$ while reinforced concrete without PS Ball only $79 \mathrm{kN}$ during monotonic loading. The cyclic loading, the cumulative energy dissipation of reinforced concrete using PS Ball indicates better performance than non-PS Ball reinforced concrete and hysteresis curve of reinforced concrete using PS Ball is more stable and pinching of does not occure.
\end{abstract}

Keywords:PS Ball, Reinforced Concrete Beam, Monotonic Load, Cyclic Load, Performance.

Pengaruh Penggunaan PS Ball Terhadap Balok Beton Bertulang

Dengan Pembebanan Monotonik dan Pembebanan Siklik

(Tan Lie Ing, Ronald Simatupang, dan Deni Setiawan) 


\section{PENDAHULUAN}

Penggunaan PS Ball sebagai bahan pengganti pasir dan bahan pengisi telah dilakukan dan disimpulkan dapat digunakan sebagai bahan konstruksi bangunan. PS Ball unggul dibanding pasir dalam hal kuat tekan, kekerasan, dan anti-weathering. Strukturnya sangat kuat, tahan cuaca, dan tidak mudah aus dengan bentuk bulat mengkilap.PS Ball tidak berbahaya, ramah lingkungan, dan dihasilkan oleh teknologi yang bebas pengaruh negatif terhadap lingkungan.

Bahan konstruksi bangunan yang sering digunakan adalah beton karena memiliki banyak kelebihan dibandingkan dengan bahan lain. Inovasi material ramah lingkungan terus dikembangkan. Berdasarkan kedua hal tersebut maka dilakukan penelitianpengaruh penggunaan PS Ball pada balok beton bertulang dengan pembebanan monotonik dan pembebanan gempa/siklik.

Tujuan utama penelitian adalah mengevaluasi pengaruh penggunaan PS Ball terhadap balok beton bertulang dengan pembebanan monotonik dan pembebanan siklik serta menganalisis perilaku elemen struktur setelah dibebani dengan beban monotonik dan beban siklik.Kuat tekan yang digunakan sebesar 25 MPa dan mutu beton sebesar 20 MPa. Benda uji pengujian beban monotonik yaitu 1 benda uji balok beton bertulang tanpa PS Ball dan satu benda uji balok beton bertulang menggunakan PS Ball sebagai pengisi dalam campuran beton. Jumlah benda uji yang sama dilakukan untuk pembebanan siklik.PS Ball yang digunakan adalah hasil produksi P.T. Purna Baja dengan ukuran saringan No. 100-200.

\section{STUDI PUSTAKA}

\subsection{Beton}

Beton merupakan salah satu bahan konstruksi yang umum digunakan untuk bangunan gedung, jembatan, jalan, dan lain lain. Beton merupakan suatu kesatuan yang homogen. Beton diperoleh dengan cara mencampur agregat halus (pasir), agregat kasar (kerikil), air, dan semen. Selain itu dapat diberi bahan tambahan yang bersifat kimiawi ataupun fisikal pada perbandingan tertentu sampai menjadi satu kesatuan yang homogen.

\subsection{Tegangan dan Regangan Beton}

Tegangan didefinisikan sebagai tahanan terhadap gaya-gaya luar. Intensitas gaya yaitu gaya per satuan luas disebut tegangan dan diberi notasi huruf Yunani “ $\sigma$ " (sigma). Tegangan dihitung menggunakan Persamaan 2.1. 


$$
\sigma=\frac{P}{A}
$$

dengan:

$\sigma=$ Tegangan (MPa)

$P=$ Gaya aksial $(\mathrm{N})$

$A=$ Luas penampang benda uji $\left(\mathrm{mm}^{2}\right)$

Jika suatu benda ditarik atau ditekan, gaya $P$ yang diterima benda mengakibatkan adanya ketegangan antar partikel dalam material yang besarnya berbanding lurus. Perubahan tegangan partikel ini menyebabkan adanya pergeseran struktur material regangan atau himpitan yang besarnya juga berbanding lurus. Pergeseran menyebabkan terjadi perubahan bentuk material. Rasio perbandingan antar $\Delta L$ terhadap $L$ disebut strain (regangan) dan dilambangkan dengan " $\varepsilon$ " (epsilon). Regangan dihitung menggunakan Persamaan 2.2.

$$
\varepsilon=\frac{\Delta L}{L}
$$

dengan:

$\varepsilon \quad=$ Regangan $(\mu \varepsilon$ atau $\mu \mathrm{m} / \mathrm{m})$

$\Delta L \quad=$ Perubahan panjang benda $(\mu \mathrm{m})$

$L \quad$ = Panjang benda mula-mula (m)

Kurva tegangan-regangan pada Gambar 2.1 menampilkan hasil yang dicapai dari hasil uji tekan terhadap sejumlah silinder uji beton standar berumur 28 hari.Semakin tinggi mutu beton, modulus elastisitasnya semakin besar. Beton dengan kekuatan lebih tinggi bersifat lebih getas (brittle); beton dengan kekuatan lebih rendah lebih ductile (ulet) daripada beton berkekuatan lebih tinggi, artinya beton tersebut akan mengalami regangan yang lebih besar sebelum mengalami kegagalan (failure).

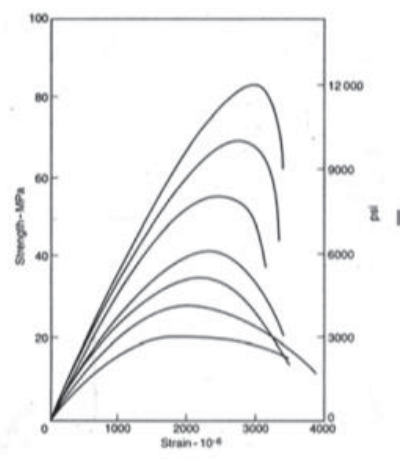

\section{Gambar 2.1 Contoh Kurva Tegangan-Regangan Pada Beton Dengan Berbagai Variasi Kuat Tekan \\ Sumber: Neville, A.M., 2003}




\subsection{Klasifikasi Beton}

Menurut SNI 03-2847-2002, beton berdasarkan berat satuannya diklasifikasikan menjadi tiga, antara lain:

1. Beton ringan: berat satuan $\leq 1.900 \mathrm{~kg} / \mathrm{m}^{3}$

2. Beton normal: berat satuan antara $2.200 \mathrm{~kg} / \mathrm{m}^{3}-2.500 \mathrm{~kg} / \mathrm{m}^{3}$

3. Beton ringan: berat satuan $>2.500 \mathrm{~kg} / \mathrm{m}^{3}$

Menurut SNI 03-6468-2002, beton berdasarkan kuat tekan diklasifikasikan menjadi tiga, antara lain:

1. Beton mutu rendah (low stength concrete) $: f_{c}{ }^{\prime}<20 \mathrm{MPa}$

2. Beton mutu sedang (medium strength concrete) $: f_{c}{ }^{\prime}=21 \mathrm{Mpa}-40 \mathrm{MPa}$

3. Beton mutu tinggi (high stength concrete) $f_{c}{ }^{\prime} \geq 41 \mathrm{MPa}$

\subsection{Jenis Beton}

Beton terdiri atas beberapa jenis, antara lain:

1. Beton normal, yaitu beton yang menggunakan agregat normal seperti semen, pasir, kerikil, dan air tanpa campuran bahan lain.

2. Beton bertulang, yaitu beton yang menggunakan tulangan dengan jumlah dan luas tulangan tidak kurang dari nilai minimum yang disyaratkan, dengan atau tanpa pratekan dan direncanakan berdasarkan asumsi bahwa kedua material bekerja bersama-sama dalam menahan gaya yang bekerja.

3. Beton pracetak, yaitu elemen beton tanpa atau dengan tulangan yang dicetak di tempat yang berbeda dari posisi akhir elemen dalam struktur.

4. Beton prestress (pratekan), yaitu beton bertulang dimana telah diberikan tegangan dalam untuk mengurangi tegangan tarik potensial dalam beton akibat pemberian beban yang bekerja.

5. Beton ringan total atau beton ringan berpasir, yaitu beton yang seluruh agregat terdiri dari agregat halus dengan berat normal.

6. Beton ringan struktural, yaitu beton yang mengandung agregat ringan yang memenuhi ketentuan dan persyaratan ASTMC330 dan mempunyai unit massa kering udara seperti yang ditentukan oleh ASTMC567.

\subsection{Material Penyusun Beton}

Beton umumnya tersusun dari tiga bahan penyusun utama yaitu semen, agregat, dan air. Semen merupakan bahan campuran yang secara kimiawi aktif setelah berhubungan dengan air. Agregat tidak berperan penting dalam reaksi kimia tersebut, 
tetapi berfungsi sebagai bahan pengisi mineral yang dapat mencegah perubahanperubahan volume beton setelah pengadukan selesai dan memperbaiki keawetan beton yang dihasilkan.

Pada umumnya beton mengandung rongga udara sekitar 1\% sampai $2 \%$, pasta semen (semen dan air) sekitar 25\% sampai 40\%, dan agregat (agregat halus dan agregat kasar) sekitar 60\% sampai 75\%. Untuk mendapatkan kekuatan yang baik tergantung pada sifat dan karakteristik dari masing-masing bahan penyusun.

\subsection{Pembebanan}

Pembebanan yang diaplikasikan pada benda uji dibagi menjadi dua jenis pembebanan, yaitu pembebanan monotonik dan pembebanan siklik. Pembebanan monotonik adalah pembebanan satu arah terhadap struktur beban nol hingga yang menyebabkan struktur mencapai kehancuran. Pengaturan pembebanan yang penting dalam pengujian ini adalah pengaturan kecepatan pembebanan. Pada penelitian ini dilakukan dengan kecepatan pembebanan sebesar 0,03mm/detik, kecepatan pembebanan ditentukan sama untuk setiap jenis pembebanan yang diaplikasikan pada benda uji.

Pada pembebanan siklik terjadi perubahan arah pembebanan pada struktur bangunan yang diakibatkan oleh gempa bumi. Pembebanan siklik dianggap selesai jika beban puncak yang dapat diterima oleh struktur pada suatu siklus tertentu mengalami penurunan. Pola pembebanan siklik yang diaplikasikan pada benda uji dibagi menjadi 10 grup. Gaya diberikan pada satu arah pembebanan dari defleksi nol hingga mencapai defleksi tertentu, kemudian arah gaya diubah berlawanan hingga defleksi balok mencapai nilai tertentu. Batasan defleksi dalam satu grup pembebanan mengacu pada defleksi leleh dan kelipatannya. Seluruh pembebanan dilakukan dengan kecepatan 0,03 mm/detik. Gambar 2.2 menunjukkan pola pembebanan siklik yang diterapkan.

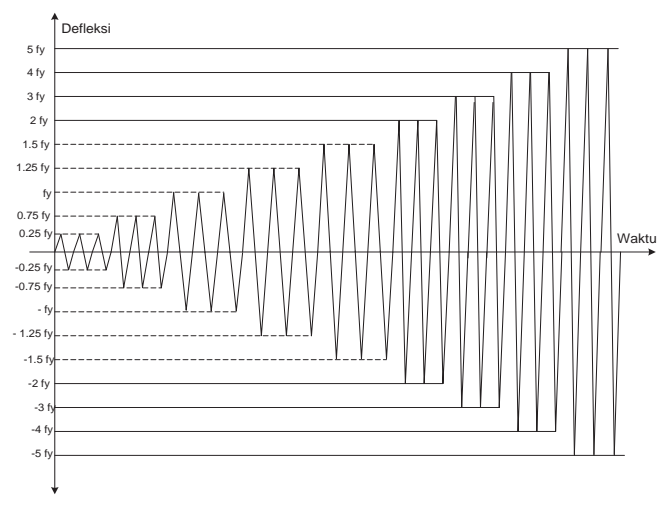

Gambar 2.2 Pola Pembebanan Siklik

Pengaruh Penggunaan PS Ball Terhadap Balok Beton Bertulang

Dengan Pembebanan Monotonik dan Pembebanan Siklik

(Tan Lie Ing, Ronald Simatupang, dan Deni Setiawan) 


\subsection{Daktilitas}

Dalam perencanaan struktur bangunan khususnya terhadap beban gempa, parameter daktilitas merupakan salah satu parameter yang penting untuk menentukan deformasi maksimum yang dapat dicapai oleh struktur yang masih mampu mempertahankan kekuatannya sebelum runtuh. Daktilitas ultimit didefinisikan sebagai rasio peralihan atap saat kondisi maksimum $(\Delta \mathrm{u})$ terhadap peralihan atap saat leleh $(\Delta \mathrm{y})$. Daktilitas ultimit dihitung menggunakan Persamaan 2.3.

$$
\mu_{\mathrm{u}}=\frac{\Delta_{\mathrm{u}}}{\Delta_{\mathrm{y}}}
$$

\subsection{Disipasi Energi}

Energi Total yang diberikan kepada struktur didefinisikan sebagai energi input. Berdasarkan sifat bahan struktur energi input terdiri dari energi elastis dan inelastik yang bersifat (terdisipasi). Disipasi energi umumnya terlihat dalam bentuk kerusakan pada elemen struktur. Energi disipasi didefinisikan sebagai luas daerah yang dibatasi oleh kurva histeresis gaya lateral-peralihan atap pada setiap siklus pembebanan.

\subsection{Pola Retak Beton}

Pada saat struktur beton bekerja menahan beban-beban yang dipikulnya, balok beton akan mengalami tegangan-tegangan pada badannya. Beton tanpa retak biasanya terjadi pada beban-beban kecil ketika tegangan-tegangan tarik masih lebih rendah daripada modulus keruntuhan (tegangan tarik lentur pada saat beton mulai retak), seluruh penahan melintang balok menahan lentur, dengan tekan pada satu sisi dan sisi lainnya. Ketika beton mulai retak diakibatkan karena beban terus ditingkatkan melampaui modulus keruntuhan balok, retak mulai terjadi di bagian bawah balok. Momen pada saat retak ini mulai terbentuk yaitu ketika tegangan tarik dibagian bawah balok sama dengan modulus keruntuhan yang disebut momen retak, $\mathrm{M}_{\mathrm{cr}}$. Jika beban ini terus ditingkatkan, retak ini mulai menyebar dan mendekati sumbu netral. Retak terjadi pada tempat-tempat disepanjang balok dimana momen aktualnya lebih besar daripada momen retak.

Selain retak lentur, pada umumnya juga terjadi retak geser. Hal ini disebabkan oleh penyaluran pembebanan pada masing-masing balok tidak sama. Retak geser merupakantanda bahwa retak tarik mulai terjadi dan merupakan kelanjutan dari retak lentur. Retak geser tidak diperbolehkan dalam pengujian lentur maupun konstruksi bangunan, karena akibat retak geser suatu bangunan akan langsung runtuh dalam seketika. Jenis kegagalan lentur dapat dilihat pada Gambar 2.2. 


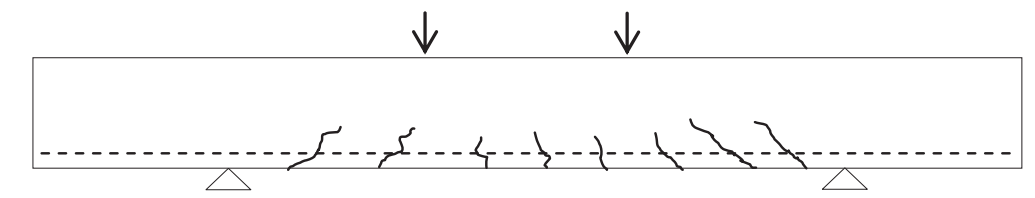

Gambar 2.2 Kegagalan Lentur

Sumber: Nilson Arthur H, David Darwin, Charles W. Dolan, 2010

Pada dasarnya ada 3 jenis retak pada struktur (Gambar 2.3), yaitu:

1. Retak lentur murni (flexural crack), retak yang terjadi di daerah yang mempunyai momen lentur besar. Arah retak hampir tegak lurus sumbu balok.

2. Retak geser lentur (flexural shear crack), retak yang terjadi pada bagian balok yang sebelumnya terjadi keretakan lentur. Retak geser lentur merupakan perambatan retak miring dari retak yang sudah terjadi sebelumnya.

3. Retak geser murni (shear crack), retak yang terjadi pada daerah dimana gaya geser maksimum bekerja dan tegangan normal sangat kecil.

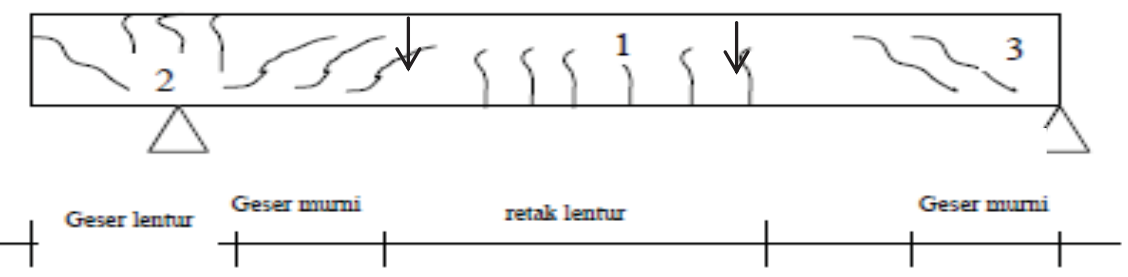

\section{Gambar 2.3 Jenis-jenis Retak pada Balok Sumber: Pratikto, 2009}

\subsection{PS Ball}

Slag EAF merupakan produk samping dengan volume besar yang terbentuk dalam proses pembuatan baja (15\% sampai 20\% dari kapasitas baja cair) dimana masih mengandung sisa-sisa metal. Teknologi slag atomizing (Slag Atomizing Technology: $S A T$ ) merupakan sistem baru untuk membentuk slag cair menjadi butiran kecil (atomize) dari Electric Arc Furnace (EAF) dengan efisiensi tinggi. Material hasil dari proses SAT berbentuk bola dengan diameter dan ukuran yang berbeda-beda, dan disebut PS (Precious Slag) Ball. Pada 1 Desember 2008 SATPlant di P.T. Purna Baja Harsco (kawasan pabrik P.T. Krakatau Steel) mulai beroperasi, dengan kapasitas 5.000 ton per bulan.

SAT merupakan proses merubah slag cair $\left(1500^{\circ} \mathrm{C}-1550^{\circ} \mathrm{C}\right)$ menjadi bola-bola kecil dengan diameter berkisar antara 0,1 mm sampai 4,5 mm. Dengan bantuan air, aliran udara berkecepatan tinggi menghasilkan pertukaran panas yang cepat dan mengubah aliran slag menjadi bola-bola (PS Ball) dengan permukaan yang mengkilap. PS Ball 
memiliki 4 ukuran dari butir kasar sampai dengan butir halus, yaitu 4-10 MESH, 10-20 MESH, 20-40 MESH, dan 40-200 MESH.

PS Ball produk ramah lingkungan hasil olahan limbah B3 yang dapat digunakan untuk material blasting sebagai pengganti pasir kuarsa. Pada Gambar 2.4 dapat dilihat proses produksi PS Ball.

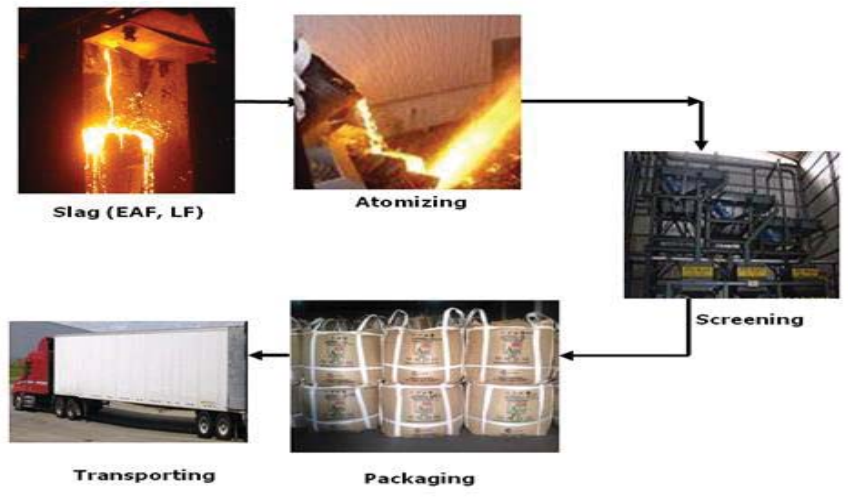

\section{Gambar 2.4 Proses Produksi PS Ball Sumber: P.T. Purna Baja Harsco}

Dalam proses SAT, slag cair didinginkan dengan cepat oleh udara dan air berkecepatan tinggi. Berbagai unsur tidak stabil membentuk $\mathrm{CaO}-\mathrm{Fe}_{2} \mathrm{O}_{3}, \mathrm{SiO}_{2}-\mathrm{Fe}_{2} \mathrm{O}_{3}$ dan $\mathrm{Mg}-\mathrm{Fe}_{2} \mathrm{O}_{3}$. Tidak ada $\mathrm{CaO}$ bebas di dalam produk, dan permukaan akan mengkilap dengan adanya struktur spinel. Struktur spinel merupakan bentuk kombinasi dari CaO$\mathrm{Fe}_{2} \mathrm{O}_{3}, \mathrm{CaO}-\mathrm{SiO}_{2}$. Pada Gambar 2.5 dapat dilihat bentuk butiran PS Ball.
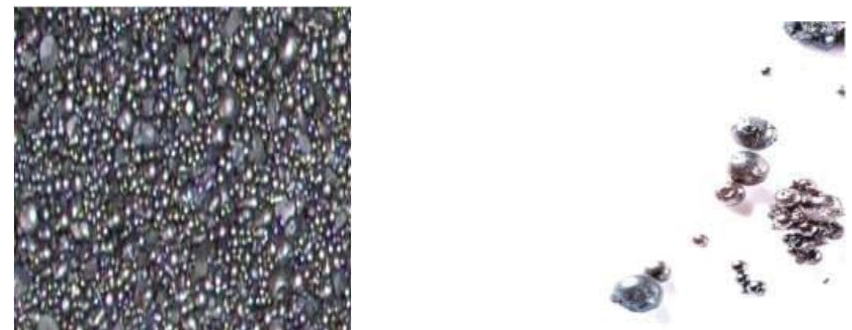

Gambar 2.5 Karakteristik PS Ball Sumber: P.T. Purna Baja Harsco

PS Ball cocok untuk berbagai penerapan, berkat sifat fisik dan kimianya. Yang paling penting adalah fakta PS Ball tidak berbahaya dan ramah lingkungan dan dihasilkan oleh teknologi yang bebas pengaruh negatif terhadap lingkungan. Struktur kimiawi dari PS Ball dapat dilihat pada Gambar 2.6. 


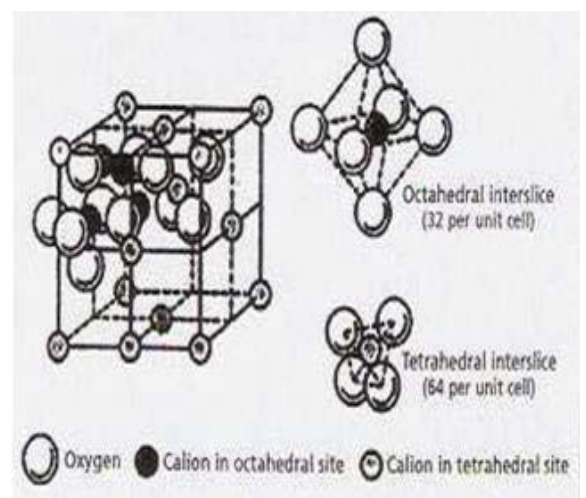
Gambar 2.6 Struktur Spinel PS Ball
Sumber: P.T. Purna Baja Harsco

Struktur spinel merupakan ciri utama material ini. Struktur fisik dan kimia yang stabil yang menghilangkan alasan polusi. Nilai persentase kandungan kimiawi dari PS Ball dapat dilihat pada Tabel 2.1.

Tabel 2.1 Persentase Kandungan Kimiawi PS Ball

\begin{tabular}{lc}
\hline Kandungan Kimia & Nilai \\
\hline $\mathrm{T}-\mathrm{Fe}$ & $20,83 \%$ \\
\hline $\mathrm{M}-\mathrm{Fe}$ & $<0,10 \%$ \\
\hline $\mathrm{FeO}$ & $3,35 \%$ \\
\hline $\mathrm{Fe}_{2} \mathrm{O}_{3}$ & $26,06 \%$ \\
\hline $\mathrm{SiO}_{2}$ & $12,69 \%$ \\
\hline $\mathrm{CaO}$ & $40,30 \%$ \\
\hline $\mathrm{Al}_{2} \mathrm{O}_{3}$ & $2,20 \%$ \\
\hline $\mathrm{MgO}$ & $7,95 \%$ \\
\hline $\mathrm{Na} 2 \mathrm{O}$ & $<0,10 \%$ \\
\hline Kekerasan & $739,8 \mathrm{HVC}$ \\
\hline Diameter & $0,1-4,5 \mathrm{~mm}$ \\
\hline Massa Jenis & $2,3 \mathrm{~kg} / \mathrm{l}$ \\
\hline Permeabilitas Air & $530 \mathrm{~cm} / \mathrm{s}$ \\
\hline Kekuatan Tekan & $323 \mathrm{~kg} / \mathrm{cm}{ }^{3}$ \\
\hline
\end{tabular}

Sumber: P.T. Purna Baja Harsco

Karakteristik material PS Ball dibandingkan dengan material lain yang ada dapat diihat pada Tabel 2.2. 
Tabel 2.2 Karakteristik Material PS Ball

\begin{tabular}{cccccc}
\hline Classification & PS Ball & Sand & Garnet & Glass Bead & Stell Ball \\
\hline $\begin{array}{c}\text { Actual Specific } \\
\text { Gravity }\end{array}$ & 3,45 & 2,62 & 4,2 & 2,6 & 7,2 \\
\hline $\begin{array}{c}\text { Mohs Hardness } \\
\text { Rockwell }\end{array}$ & 7,5 & 5,5 & 7,5 & 5 & 8,5 \\
\hline $\begin{array}{c}\text { Hardness (HRC) } \\
\text { Brightness } \\
\text { (quality grade) }\end{array}$ & Very good & Normal & Good & Normal & Very good \\
\hline $\begin{array}{c}\text { Reusability } \\
\text { Sumber: P.T. Purna Baja Harsco }\end{array}$ & $1-3$ times & One time & $1-3$ times & One time & 5-7 times \\
\hline
\end{tabular}

\section{METODE PENELITIAN}

Tahapan penelitian dapat dilihat pada Gambar 3.1.Standar pengujian yang digunakan adalah Standar Nasional Indonesia (SNI). Kadar PS Ball yang digunakan berdasarkan hasil penelitian terdahulu adalah $15 \%$.

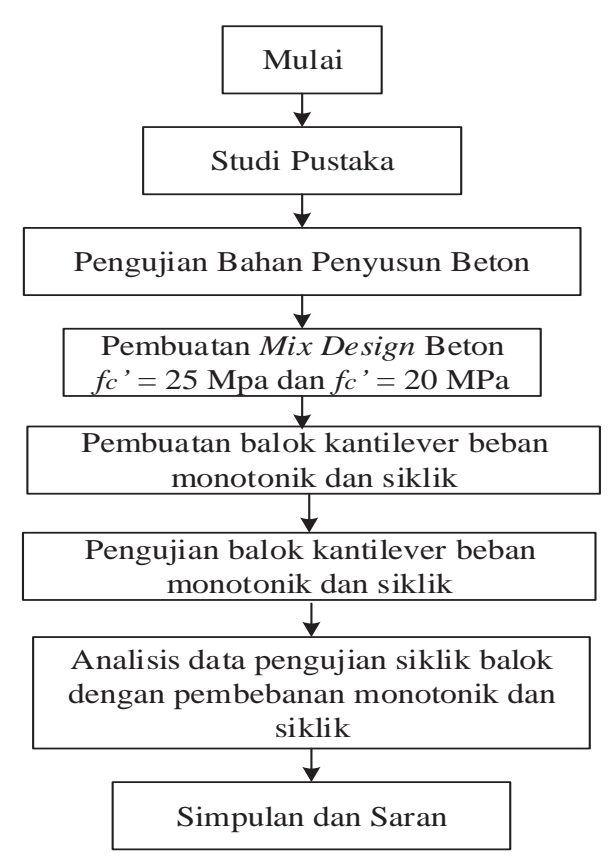

Gambar 3.1 Flowchart Penelitian 
Balok uji yang digunakan dalam pengujian merupakan balok kantilever dan spesifikasi balok uji yang digunakan adalah sebagai berikut:

A. Properti benda uji balok

Gambar 3.2 memperlihatkan properti balok yang akan diuji dengan menggunakan beban monotonik dan beban siklik. Tulangan longitudinal yang digunakan adalah baja tulangan ulir diameter 16 mm sebanyak 4 buah pada tulangan tarik dan 2 buah pada tulangan tekan. Tulangan transversal menggunakan baja tulangan polos dengan diameter $8 \mathrm{~mm}$ yang dipasang sejarak $50 \mathrm{~mm}$ di sepanjang bentang balok.
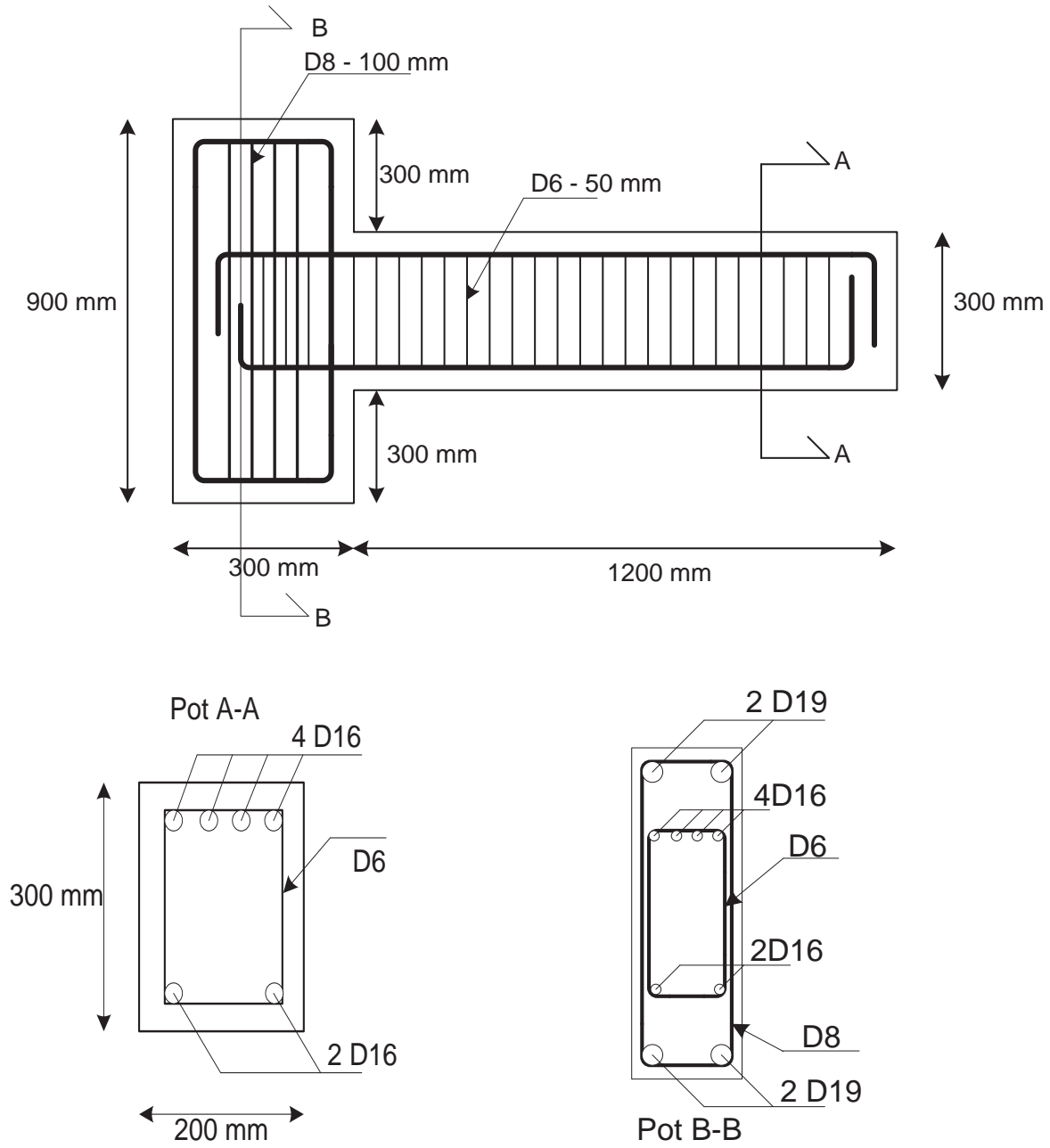

Gambar 3.2 Properti Balok Uji

Desain balok yang digunakan adalah sebagai berikut:

1. $\mathrm{fc}^{\prime}=30 \mathrm{MPa}$.

2. $f y=400 \mathrm{MPa}$.

3. $\mathrm{L}=1.2 \mathrm{~m}$.

4. $b=200 \mathrm{~mm}$. 
5. $\mathrm{h}=300 \mathrm{~mm}$.

6. $\mathrm{d}^{\prime}=40 \mathrm{~mm}$.

7. $d=h-d^{\prime}=260 \mathrm{~mm}$.

8. Tulangan tarik menggunakan tulangan ulir dengan D16 mm sebanyak 4 buah.

9. Tulangan tekan menggunakan tulangan ulir dengan D16 mm sebanyak 2 buah.

10.Tulangan transversal menggunakan tulangan polos dengan diameter $6 \mathrm{~mm}$.

B. Persyaratan-persyaratan yang harus dipenuhi dalam pendesainan sesuai dalam SNI-032847-2002 adalah sebagai berikut:

1. Persyaratan tulangan tarik

Persyaratan yang harus dipenuhi untuk tulangan tarik yang digunakan adalah sebagai berikut:

a. $\quad$ Luas tulangan yang digunakan tidak boleh lebih kecil:

$$
\begin{aligned}
& A s_{\text {min }}=\frac{\sqrt{f c^{\prime}}}{4 f y} b \times d \\
& A s_{\text {min }}=\frac{\sqrt{30}}{4 \times 400} 200 \times 260 \\
& A s_{\text {min }}=178.0098 \mathrm{~mm}^{2}
\end{aligned}
$$

Luas tulangan tarik yang digunakan dalam desain adalah sebesar $804,2477 \mathrm{~mm}^{2}$, As $>\mathrm{As}_{\min } \rightarrow 804,2477 \mathrm{~mm}^{2}>178,0098 \mathrm{~mm}^{2}$ sehingga memenuhi syarat dan tulangan yang digunakan tidak boleh lebih kecil:

$$
\begin{aligned}
& A s_{\text {min }}=\frac{1.4}{f y} b \times d \\
& A s_{\text {min }}=\frac{1.4}{400} 200 \times 260 \\
& A s_{\text {min }}=182 \mathrm{~mm}^{2}
\end{aligned}
$$

b. Jarak bersih antar tulangan tarik sejajar dalam lapis yang sama tidak boleh kurang db. Jarak antar tulangan tarik sejajar yang digunakan dalam desain sebesar $20 \mathrm{~mm}$.

2. Persyaratan tulangan tekan

a. Luas tulangan tekan yang digunakan tidak boleh lebih kecil dari:

$$
\begin{aligned}
& A s_{\text {min }}=\frac{\sqrt{f c^{\prime}}}{4 f y} b \times d \\
& A s_{\text {min }}=\frac{\sqrt{30}}{4 \times 400} 200 \times 260
\end{aligned}
$$




$$
A s_{\min }=178.0098 \mathrm{~mm}^{2}
$$

Luas tulangan tekan yang digunakan dalam desain sebesar $402.1239 \mathrm{~mm}^{2}$, sehingga As $>\mathrm{As}_{\min } \rightarrow 402.1239 \mathrm{~mm}^{2}>178.0098 \mathrm{~mm}^{2}$ sehingga memenuhi syarat dan tulangan yang digunakan tidak boleh lebih kecil dari:

$$
\begin{aligned}
& A s_{\text {min }}=\frac{1.4}{f y} b \times d \\
& A s_{\text {min }}=\frac{1.4}{400} 200 \times 260 \\
& A s_{\text {min }}=182 \mathrm{~mm}^{2}
\end{aligned}
$$

b. Jarak bersih antar tulangan sejajar dalam lapis yang sama tidak boleh kurang dari db.

3. Persyaratan tulangan transversal

a. Jarak sengkang maksimum yang digunakan tidak boleh melebihi:

- $\mathrm{d} / 4=62,5 \mathrm{~mm}$

- $\quad 8 \mathrm{~d}=128 \mathrm{~mm}$

- $24 \mathrm{db}=144 \mathrm{~mm}$

- $300 \mathrm{~mm}$

b. Jarak sengkang yang didapatkan dalam perhitungan sebesar $45 \mathrm{~mm}$ untuk semua jenis tulangan tarik dan tulangan tekan yang digunakan dalam pengujian, sehingga memenuhi syarat jarak sengkang yang dibutuhkan.

c. Disepanjang daerah dua kali tinggi $(2 \mathrm{~h}=600 \mathrm{~mm})$ balok pada kedua sisi suatu penampang dimana leleh lentur diharapkan dapat terjadi sehubungan dengan terjadinya deformasi inelastik struktur rangka.

4. Persyaratan beton

a. Kuat tekan beton yang digunakan tidak boleh kurang dari $20 \mathrm{MPa}$, kuat tekan beton yang digunakan dalam desain sebesar $30 \mathrm{MPa}$.

b. Bentang bersih balok tidak boleh kurang dari empat kali tinggi efektifnya ( $\mathrm{L}>$ 4d) $\rightarrow 1.200 \mathrm{~mm}>1.000 \mathrm{~mm}$, dalam desain digunakan bentang bersih sebesar $1.200 \mathrm{~mm}$, sehingga masih memenuhi syarat.

c. Perbandingan lebar terhadap tinggi tidak boleh kurang dari 0,3

$$
\frac{b}{h}>0.3 \rightarrow \frac{200}{300}>0.3 \rightarrow 0.6>0.3 \ldots . . O K
$$

5. Persyaratan panjang penyaluran 
Panjang penyaluran dasar $\lambda_{\text {dh }}$ untuk suatu batang terkait dengan fy sama dengan $400 \mathrm{MPa}$ (Gambar 3.3) diambil sebesar:

$$
\lambda_{d h}=\frac{100 d_{b}}{\sqrt{f c^{\prime}}}
$$

dengan:

$\lambda_{\mathrm{dh}} \quad$ : Panjang Penyaluran (mm)

$\mathrm{d}_{\mathrm{b}} \quad$ : Diameter Tulangan (mm)

fc' : Mutu Beton (MPa)

$$
\lambda_{d h}=\frac{100 \times 16}{\sqrt{30}}=292 \mathrm{~mm}
$$

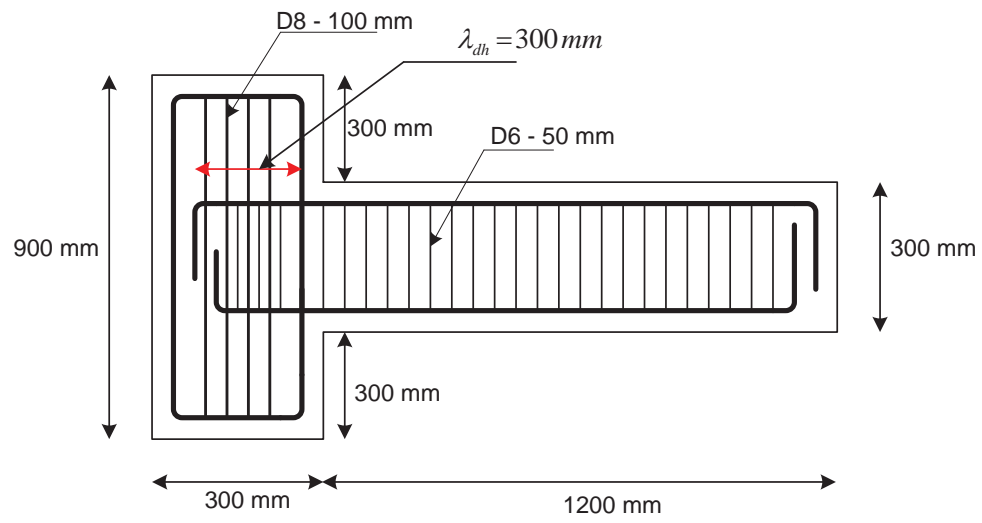

\section{Gambar 3.3 Panjang Penyaluran Tulangan}

6. Persyaratan kait yang digunakan dalam spesimen

Persyaratan kait yang digunakan dalam pengujian dapat dilihat pada Gambar 3.4.

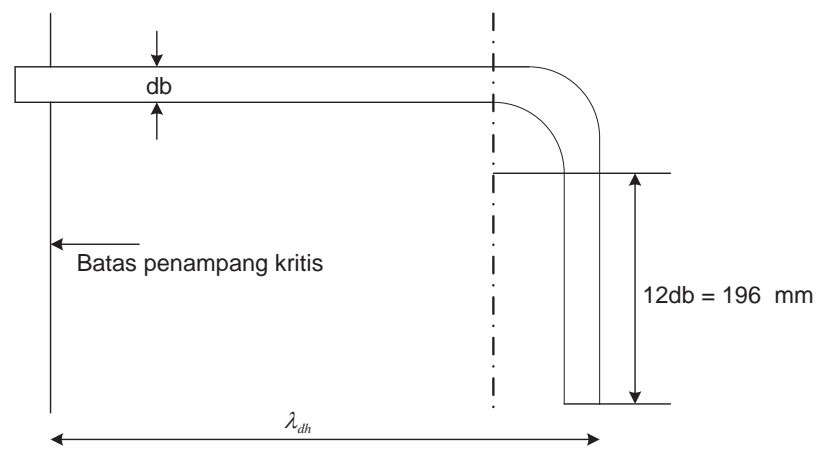

Gambar 3.4 Kait 


\section{ANALISIS DATA DAN PEMBAHASAN}

\subsection{Analisis Pengujian Balok Beton Bertulang Menggunakan PS Ball dan Balok Beton Bertulang Tanpa PS Ball Dengan Beban Monotonik}

Hasil pengujian diperoleh beban leleh balok beton bertulang menggunakan PS Ball ketika dibebani dengan beban monotonik adalah sebesar $50 \mathrm{kN}$ dengan displacement leleh sebesar $20 \mathrm{~mm}$. Pada kondisi ultimate balok beton bertulang menggunakan PS Ball dapat menahan beban sebesar 79,01 kN dan mengalami keruntuhan pada saat displacement mencapai $135 \mathrm{~mm}$. Daktilitas perpindahan ditentukan dari perbandingan perpindahan ultimate terhadap perpindahan leleh dari balok, diperoleh daktilitas tulangan sebesar 6,5.

Hasil pengujian balok beton bertulang tanpa PS Balldidapatkan beban leleh dengan beban monotonik adalah sebesar 48,5 kN dengan displacement leleh sebesar 14,5 mm. Balok beton bertulang tanpa PS Ball dapat menahan beban hingga sebesar $90 \mathrm{kN}$. Balok beton bertulang tanpa PS Ball mengalami keruntuhan pada saat displacement mencapai 66,4 mm. Daktilitas perpindahan balok beton bertulang tanpa PS Ball yang didapat dari hasil pengujian dengan menggunakan beban monotonik adalah sebesar 4,5. Hal ini menunjukkan bahwa balok beton bertulang menggunakan PS Ball lebih daktail daripada balok beton bertulang tanpa PS Ball.

Perbandingan hasil pengujian balok beton bertulang menggunakan PS Ball dan balok beton bertulang tanpa PS Ball mengenai perilakunya ketika diberi beban monotonik dapat dilihat pada Tabel 4.1. Pola keruntuhan pada balok beton bertulang tanpa PS Ball dengan beban monotonik dapat dilihat pada Gambar 4.1 dan pola keruntuhan pada balok beton bertulang menggunakan PS Ball dengan beban monotonik dapat dilihat pada Gambar 4.2.

Tabel 4.1 Perbandingan Balok Beton Bertulang Menggunakan PS Ball dan Balok Beton Bertulang Tanpa PS Ball Dengan Beban Monotonik

\begin{tabular}{ccccccc}
\hline & \multicolumn{2}{c}{ Kurvatur } & \multicolumn{2}{c}{ Momen $(\mathrm{kNm})$} & \multicolumn{2}{c}{ Beban (kN) } \\
\cline { 2 - 7 } Kondisi & $\begin{array}{c}\text { Balok } \\
\text { Menggunakan } \\
\text { PS Ball }\end{array}$ & $\begin{array}{c}\text { Balok } \\
\text { Tanpa } \\
\text { Pall }\end{array}$ & $\begin{array}{c}\text { Balok } \\
\text { Menggunakan } \\
\text { PS Ball }\end{array}$ & $\begin{array}{c}\text { Balok } \\
\text { Tanpa } \\
\text { PS } \\
\text { Ball }\end{array}$ & $\begin{array}{c}\text { Balok } \\
\text { Menggunakan } \\
\text { PS Ball }\end{array}$ & $\begin{array}{c}\text { Balok } \\
\text { Tanpa } \\
\text { PS } \\
\text { Ball }\end{array}$ \\
\hline Retak & $8,36 \mathrm{E}-06$ & $\begin{array}{c}1,45 \mathrm{E}- \\
06\end{array}$ & 23,19 & 14,64 & 15,46 & 9,76 \\
\hline Leleh & 4,2E-05 & $\begin{array}{c}2,2 \mathrm{E}- \\
\text { 06 }\end{array}$ & 75 & 72,75 & 50 & 48,5 \\
\hline Ultimate & $8,72 \mathrm{E}-05$ & $4,17 \mathrm{E}-$ & 118,1 & 134,4 & 79,01 & 90 \\
\hline
\end{tabular}




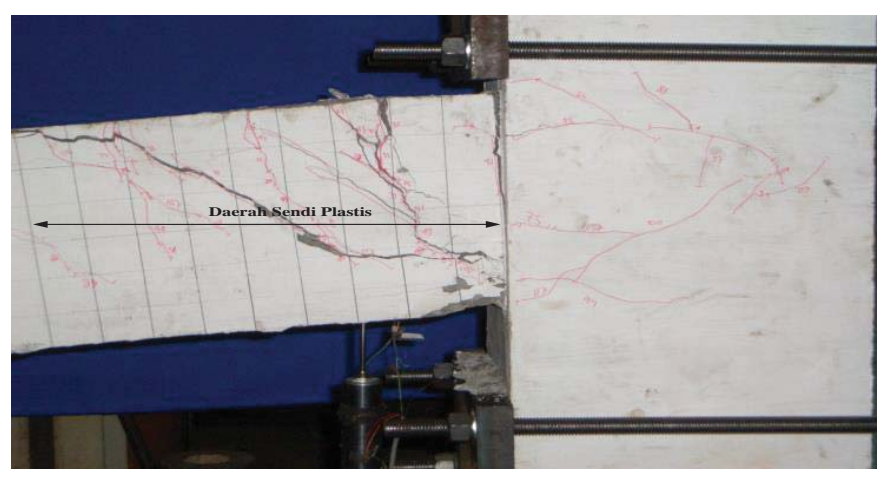

Gambar 4. 1 Pola Keruntuhan pada Balok Beton Bertulang Tanpa PS Ball dengan Pengujian Monotonik

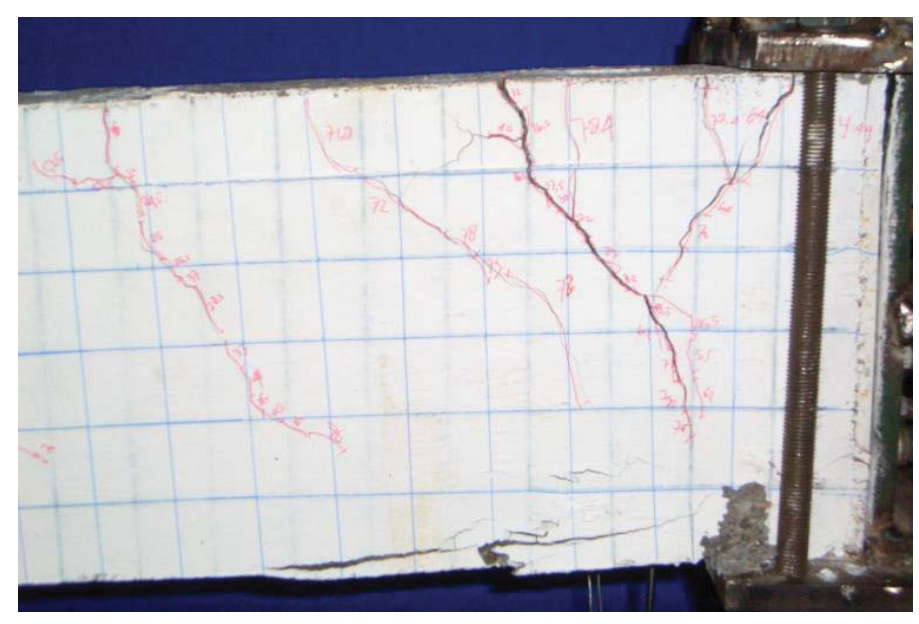

\section{Gambar 4.2 Pola Keruntuhan pada Balok Beton Bertulang Menggunakan PS Ball} dengan Pengujian Monotonik

\subsection{Analisis Pengujian Balok Beton Bertulang Menggunakan PS Ball dan Balok \\ Beton Bertulang Tanpa PS Ball Dengan Beban Siklik}

Pengujian siklik pada balok beton bertulang menggunakan PS Ball dilakukan sampai pada kondisi dimana displacement balok mencapai $4 \Delta y$. Hal ini dikarenakan balok beton bertulang sudah mencapai kondisi leleh. Besarnya energi disipasi dari balok beton bertulang menggunakan PS Ball pada saat diaplikasikan pembebanan siklik dapat dilihat pada Tabel 4.2. 
Tabel 4.2 Energi Disipasi Balok Beton Bertulang Menggunakan PS Ball

\begin{tabular}{|c|c|c|c|c|c|}
\hline \multirow{2}{*}{ Siklus } & \multicolumn{2}{|c|}{$\begin{array}{l}\text { Energi Disipasi } \\
\quad(\mathrm{kNmm})\end{array}$} & \multirow{2}{*}{$\begin{array}{c}\text { Total } \\
\text { Energi } \\
\text { Disipasi } \\
(\mathrm{kNmm})\end{array}$} & \multirow{2}{*}{$\begin{array}{c}\text { Energi } \\
\text { Disipasi } \\
\text { Rata- } \\
\text { Rata } \\
\text { (kNmm) }\end{array}$} & \multirow{2}{*}{$\begin{array}{c}\text { Energi } \\
\text { Disipasi } \\
\text { Kumulatif } \\
(\mathrm{kNmm})\end{array}$} \\
\hline & Tarik & Tekan & & & \\
\hline \multirow{2}{*}{$\begin{array}{c}0.25 \\
\Delta y\end{array}$} & 17.99 & 13.29 & 31.28 & \multirow{2}{*}{32.73} & \multirow{2}{*}{32.73} \\
\hline & 19.38 & 14.81 & 34.19 & & \\
\hline \multirow{2}{*}{$\begin{array}{l}0.5 \\
\Delta y\end{array}$} & 42.95 & 59.28 & 102.23 & \multirow{2}{*}{100.42} & \multirow{2}{*}{133.15} \\
\hline & 40.40 & 58.20 & 98.60 & & \\
\hline \multirow{2}{*}{$\begin{array}{c}0.75 \\
\Delta y\end{array}$} & 166.91 & 280.02 & 446.93 & \multirow{2}{*}{374.95} & \multirow{2}{*}{508.10} \\
\hline & 109.71 & 193.27 & 302 & & \\
\hline \multirow{2}{*}{$\Delta \mathrm{y}$} & 242.38 & 522.12 & 764.49 & \multirow{2}{*}{733.76} & \multirow{2}{*}{1241.86} \\
\hline & 212.28 & 490.74 & 703.02 & & \\
\hline \multirow{2}{*}{$\begin{array}{l}1.25 \\
\Delta \mathrm{y}\end{array}$} & 402.03 & 899.31 & 1301.34 & \multirow{2}{*}{1404.32} & \multirow{2}{*}{2646.18} \\
\hline & 431.47 & 1075.82 & 1507.29 & & \\
\hline \multirow{2}{*}{$\begin{array}{l}1.5 \\
\Delta \mathrm{y}\end{array}$} & 681.82 & 1624.38 & 2306.21 & \multirow{2}{*}{2389.01} & \multirow{2}{*}{5035.19} \\
\hline & 710.30 & 1761.51 & 2471.81 & & \\
\hline \multirow{2}{*}{$2 \Delta y$} & 1203.44 & 2857.47 & 4060.90 & \multirow{2}{*}{4212.72} & \multirow{2}{*}{9247.91} \\
\hline & 1275.60 & 3088.94 & 4364.54 & & \\
\hline \multirow{2}{*}{$3 \Delta y$} & 2594.03 & 5867.37 & 8461.40 & \multirow{2}{*}{7949.39} & \multirow{2}{*}{17197.30} \\
\hline & 2499.79 & 4937.60 & 7437.39 & & \\
\hline \multirow{2}{*}{$4 \Delta y$} & 3763.56 & 8908.68 & 12672.24 & \multirow{2}{*}{12672.24} & \multirow{2}{*}{29869.54} \\
\hline & - & - & - & & \\
\hline
\end{tabular}

Energi disipasi rata-rata adalah nilai rata-rata dari total energi disipasi pada setiap siklus. Energi disipasi kumulatif merupakan penjumlahan secara kumulatif dari energi disipasi rata-rata. Total disipasi energi kumulatif balok beton bertulang menggunakan PS Ball adalah sebesar 29869,54 kNmm. Pola keruntuhan yang terjadi pada balok beton bertulang menggunakan PS Ball adalah keruntuhan akibat lentur. Hal ini dapat dilihat dari pola retak yang terjadi pada spesimen yaitu retakan yang terjadi berupa retakan vertikal. Beban tekan maksimum yang dapat dipikul tulangan tarik pada balok beton bertulang menggunakan PS Ball adalah sebesar 112,20 kN. Pada kurva histerisis terjadi pinching pada balok beton bertulang tanpa PS Ball. Penurunan disipasi energi semakin besar seiring dengan semakin bertambahnya beban, dapat dilihat pada Tabel 4.3. Perbedaan energi disipasi kumulatif antara balok beton bertulang menggunakan PS Ball dan balok beton bertulang tanpa PS Ball adalah sebesar 50\%. Gambar 4.3 memperlihatkan perbandingan kurva histerisis balok beton bertulang menggunakan PS Ball dan balok beton bertulang tanpa PS Ball. 
Tabel 4.3 Energi Disipasi Balok Beton Bertulang Tanpa PS Ball

\begin{tabular}{|c|c|c|c|c|c|}
\hline \multirow{2}{*}{ Siklus } & \multicolumn{2}{|c|}{$\begin{array}{l}\text { Energi Disipasi } \\
\qquad(\mathrm{kNmm})\end{array}$} & \multirow{2}{*}{$\begin{array}{c}\text { Total } \\
\text { Energi } \\
\text { Disipasi } \\
(\mathrm{kNmm})\end{array}$} & \multirow{2}{*}{$\begin{array}{c}\text { Energi } \\
\text { Disipasi } \\
\text { Rata- } \\
\text { Rata } \\
\text { (kNmm) }\end{array}$} & \multirow{2}{*}{$\begin{array}{c}\text { Energi } \\
\text { Disipasi } \\
\text { Kumulatif } \\
\text { Rata-Rata } \\
(\mathrm{kNmm})\end{array}$} \\
\hline & Tarik & Tekan & & & \\
\hline \multirow{2}{*}{$0.25 \Delta y$} & 9.12 & 19.31 & 28.42 & \multirow{2}{*}{26.66} & \multirow{2}{*}{26.66} \\
\hline & 11.75 & 13.14 & 24.89 & & \\
\hline \multirow{2}{*}{$0.5 \Delta y$} & 27.88 & 49.77 & 77.65 & \multirow{2}{*}{75.78} & \multirow{2}{*}{102.44} \\
\hline & 25.09 & 48.82 & 73.91 & & \\
\hline \multirow{2}{*}{$0.75 \Delta y$} & 51.98 & 100.59 & 77 & \multirow{2}{*}{140.22} & \multirow{2}{*}{242.66} \\
\hline & 46.22 & & & & \\
\hline \multirow{2}{*}{$\Delta y$} & 103.12 & 206 & 309.89 & \multirow{2}{*}{307.23} & \multirow{2}{*}{549.89} \\
\hline & 100.18 & 204 & 304.57 & & \\
\hline \multirow{2}{*}{$1.25 \Delta y$} & 155.40 & 319.58 & 474.98 & \multirow{2}{*}{467.43} & \multirow{2}{*}{1017.32} \\
\hline & 149.13 & 310.75 & 459.88 & & \\
\hline \multirow{2}{*}{$1.5 \Delta y$} & 208.37 & 472.74 & 681.11 & \multirow{2}{*}{677.17} & \multirow{2}{*}{1694.49} \\
\hline & 206.90 & 466.34 & 673.23 & & \\
\hline \multirow{2}{*}{$2 \Delta y$} & 378.29 & 849.42 & 1227.71 & \multirow{2}{*}{1224.60} & \multirow{2}{*}{2919.09} \\
\hline & 372.64 & 848.85 & 1221.49 & & \\
\hline \multirow{2}{*}{$3 \Delta y$} & 958.96 & 2231.80 & 3190.76 & \multirow{2}{*}{2814.87} & \multirow{2}{*}{5733.96} \\
\hline & 767.11 & 1671.87 & 2438.98 & & \\
\hline \multirow{2}{*}{$4 \Delta y$} & 1374.79 & 3329.47 & 4704.25 & \multirow{2}{*}{4161.73} & \multirow{2}{*}{9895.69} \\
\hline & 1141.40 & 2477.80 & 3619.21 & & \\
\hline \multirow{2}{*}{$5 \Delta y$} & 1730.28 & 4315.03 & 6045.31 & \multirow{2}{*}{5210.49} & \multirow{2}{*}{15106.18} \\
\hline & 1265.22 & 3110.46 & 4375.68 & & \\
\hline
\end{tabular}

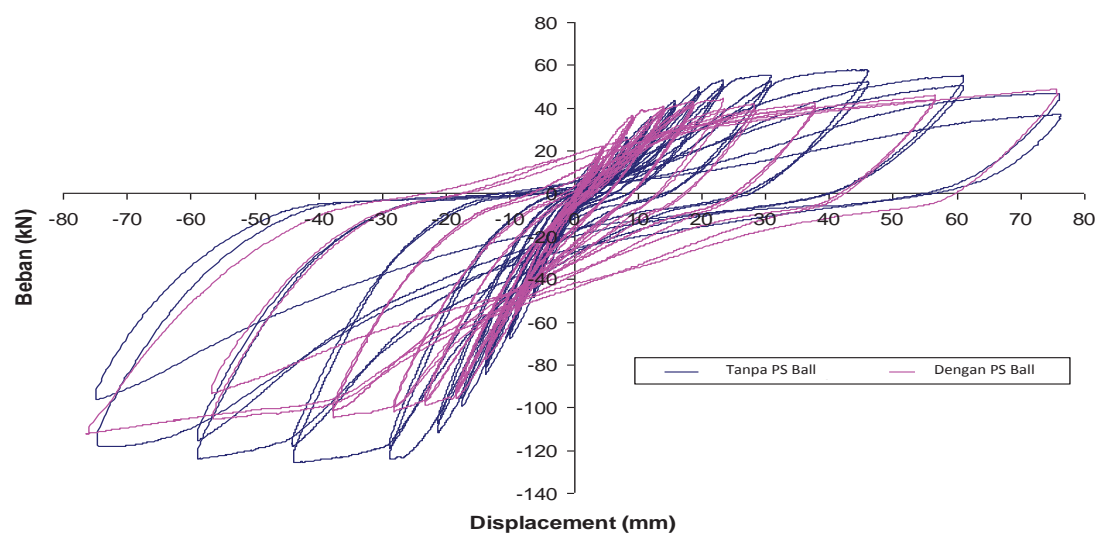

Gambar 4.3 Perbandingan Kurva Histerisis Balok Beton Bertulang Menggunakan PS Ball dan Balok Beton Bertulang Tanpa PS Ball 
Beban puncak balok beton bertulang tanpa PS Ball lebih tinggi daripada balok beton bertulang menggunakan PS Ball. Selain itu kurva histerisis balok beton bertulang menggunakan PS Ball lebih stabil daripada balok beton bertulang tanpa PS Ball. Hal ini dapat dilihat dari kurva histeresis dimana semakin besar pembebanan yang diaplikasikan pada balok maka kurva histerisis yang terbentuk semakin besar. Pada kurva histerisis balok beton bertulang menggunakan PS Ball tidak terjadi pinching seperti yang terjadi pada balok beton bertulang tanpa PS Ball.

Pola retak balok beton bertulang tanpa PS Ball dengan beban siklik dapat dilihat pada Gambar 4.4 dan pola retak balok beton bertulang menggunakan PS Ball dengan beban siklik dapat dilihat pada Gambar 4.5.

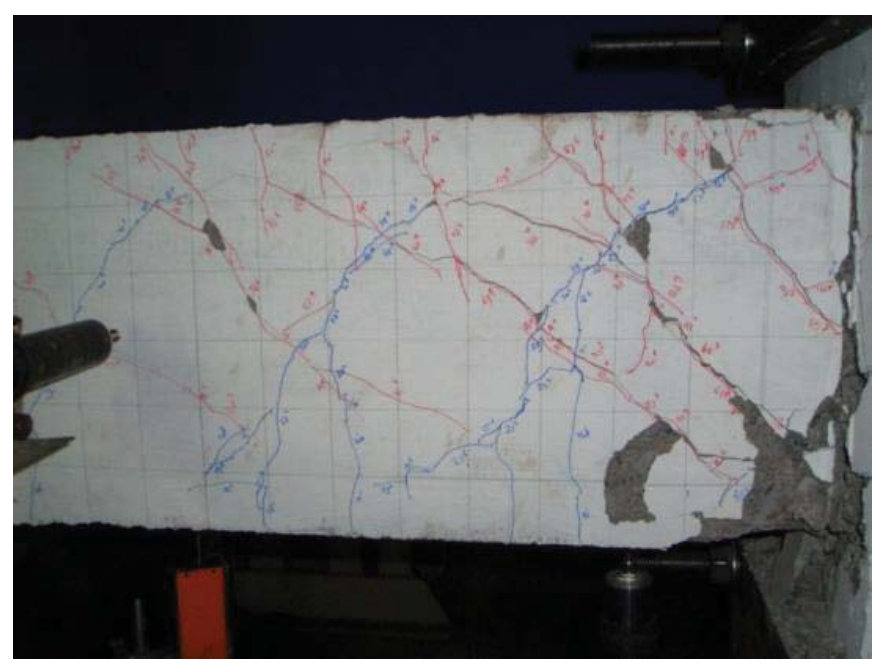

Gambar 4.4 Pola Retak Balok Beton Bertulang Tanpa PS Ball dengan Beban Siklik

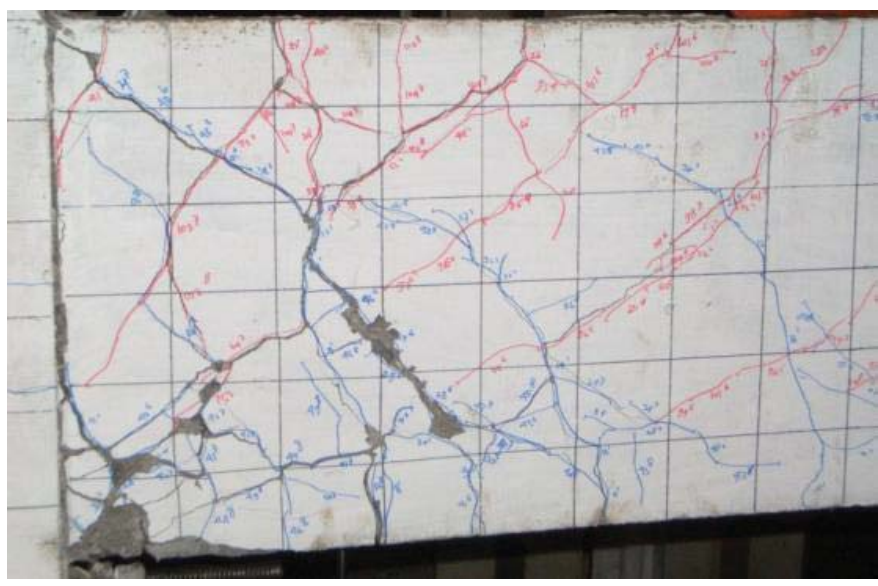

\section{Gambar 4.5 Pola Retak Balok Beton Bertulang Menggunakan PS Ball dengan Beban Siklik}

\section{SIMPULAN}


Berdasarkan hasil analisis data dan pembahasan dapat ditarik simpulan sebagai berikut:

1) Balok beton bertulang tanpa PS Ball mampu menahan beban sebesar $90 \mathrm{kN}$ sedangkan balok beton bertulang menggunakan PS Ball mampu menahan beban sebesar $79 \mathrm{kN}$. Displacement balok beton bertulang tanpa PS Ball sebesar $20 \mathrm{~mm}$ sedangkan displacement balok beton bertulang menggunakan PS Ball sebesar 14,5 $\mathrm{mm}$.

2) Hasil pengujian siklik dilihat dari disipasi energi kumulatif menyatakan bahwa balok beton bertulang menggunakan PS Ball menerima disipasi energi kumulatif lebih baik daripada balok beton bertulang tanpa PS Ball. Hal ini mengindikasikan bahwa balok beton bertulang menggunakan PS Ball performance-nya terhadap beban siklik lebih baik daripada balok beton bertulang tanpa PS Ball.

3) Hasil pengujian siklik dilihat dari kurva histerisis memperlihatkan bahwa balok beton bertulang menggunakan PS Ball lebih stabil daripada balok beton bertulang tanpa PS Ball. Selain itu, pada balok beton bertulang menggunakan PS Ball tidak terjadi pinching sedangkan balok beton bertulang tanpa PS Ball mengalami pinching.

\section{UCAPAN TERIMAKASIH}

1) Kepada Yang Terhormat, Direktur Riset dan Pengabdian Masyarakat Direktorat Jenderal Penguatan Riset dan Pengembangan Kementerian Riset, Teknologi, dan Pendidikan Tinggi yang telah mendanai penelitian ini.

2) Kepada Yang Terkasih, Ronald Simatupang yang telah memberikan ide-ide dan membantu dalam penelitian-penelitian yang telah dilaksanakan selama ini.

\section{DAFTAR PUSTAKA}

1. ACI 318-02, 2002,Building Codes Requirment for Structural Concrete and Commentary, ACI Committee.

2. ACI 374.1, 2005, Acceptance Criteria for Moment Frames Based on Structural Testing and Commentary

3. Annual book of ASTM Standard, DestignationC22, Test Method for Bulk Density (Unit Weight).

4. Annual book of ASTM Standard, Destignation C33/33M, StandardSpecification for Concrete Aggregate. 
5. Annual Book of ASTM Standard, Destignation C39a-93, Standard Specification for Concrete Agregat.

6. Annual book of ASTM Standart, Destignation C40, Test Method for Organic Impurities In Fine Aggregates for Concrete.

7. Annual Book of ASTM Standard, Destignation C78-94, Standard Practice for Making and Curing Concrete Test Specimen in Laboratory.

8. Annual book of ASTM Standard, Destignation C136, Test Method for Sieve Analysis of Fine and Coarse Aggregates".

9. Annual book of ASTM Standart, Destignation C143, Standard Test Methodfor Slump of Hydraulic Cement Concrete.

10. Annual book of ASTM Standard, Destignation C873, Standard Test Method for Compressive Strength of Concrete Cylinders Cast In Place In Cylindrical Molds.

11. Annual book of ASTM Standard, Destignation C989, Spec for Slag Cement for Use In Concrete and Mortars.

12. ASTM A706M-93a,Standard Specification for Low-Alloy Steel Deformed Bars for Concrete Reinforcement, Annual Book of ASTM Standards, Volume 01.04, pp. 353357.

13. Hamzah, A., 1999, Sifat Fisik dan Mekanik Beton Mutu Tinggi dengan Campuran Copper Slag, Tugas Akhir S-1, FTSP, ITS, 1999.

14. Idris dan Rifai, 2002, Beton.

15. Neville, A.M., 2003, Properties of Concrete.

16. SNI 03-2834-2000, 2000, TataCara Pembuatan Rencana Campuran Beton Normal.

17. SNI 03-2847-2002, 2002, Tata Cara Perhitungan Struktur Beton untuk Bangunan Gedung. 